\title{
Good and the Object of Natural Inclinations in St. Thomas Aquinas ${ }^{1}$
}

\author{
JOHN I. JENKINS
}

What is the relationship between what we, in our most reflective and circumspect moments, desire or approve of and what is our good? In this essay I will explore the views of St. Thomas Aquinas on this issue. I will develop my interpretation of Aquinas dialectically by considering and criticizing aspects of the influential interpretations of Germain Grisez ${ }^{2}$ and John Finnis, ${ }^{3}$ on one hand, and Ralph McInerny, ${ }^{4}$ on the other. ${ }^{5}$ These interpretations, I will

1. Anthony Kenny, Brian Davies, O.P., Robert George, Ralph McInerny, and David Burrell, C.S.C., were all most generous in reading and commenting upon various versions of this paper, and I am most grateful for their help. Of course, the opinions expressed herein are to be ascribed to me alone. This paper was substantially completed in January, 1991 and I have been unable to take notice of studies published since then.

2. Germain Grisez, "The First Principle of Practical Reason: A Commentary on the Summa theologiae 1-2, Question 94, Article 2," Natural Law Forum 10 (1965): 168-201.

3. John Finnis, Natural Law and Natural Rights (Oxford: Oxford University Press, 1980).

4. McInerny's criticisms of Grisez and Finnis are found in Ethica Thomistica (Washington, D.C.: Catholic University of America Press, 1982). Grisez and Finnis responded to McInerny in "The Basic Principles of Natural Law: A Reply to Ralph McInerny," American Journal of Jurisprudence 26 (1981): 21-31.

5. Grisez and Finnis's writing has set off a long and vigorous debate. Other recent contributions include the following. Robert George gives an admirably clear 
argue, founder because of improper analyses and common misunderstandings of key terms in Aquinas. Once we have a proper grasp of Aquinas's position, we can better appreciate it as the interesting and subtle ethical theory that it is.

Although the Grisez-Finnis interpretation differs from McInerny's on several points, two issues are central. Both of these issues have to do with the putative distinction between facts about our natural inclinations and our good, and one difficulty in adjudicating this debate is that the disputants fail to distinguish clearly between these distinct issues. The first concerns the question of whether Thomas thought that a subject could infer judgments about what is normatively good for herself and about what she ought (normatively) to do from some set of descriptive or factual judgments about her nature, capacities, and inclinations. We can call this the epistemological question or issue: it concerns whether Thomas thought that intellectual assent to certain propositions of one sort tends to make epistemically rational assent to certain propositions of another sort. This epistemological question is distinguishable from, though not entirely independent of, what we can call the conceptual question or issue about the nature of the normatively good for Thomas. This concerns whether Thomas thought that being the object of human inclinations is (at least partly) constitutive of the concept of good, or (to put it in more Thomistic language) of the ratio boni. We will discuss these questions consecutively. I will argue that though McInerny is nearer the truth on the first question, Grisez and Finnis are nearer the truth on the second.

summary and a brief defense of the Grisez-Finnis interpretation in "Recent Criticism of Natural Law Theory" (Book Review), University of Chicago Law Review 55 (1988): 1378-85. Douglas Flippen challenged the Grisez-Finnis view in "Natural Law and Natural Inclinations," New Scholasticism 60 (1986): 284-316, and Grisez responded with a defense of his interpretation in "Natural Law and Natural Inclinations: Some Comments and Clarifications," New Scholasticism 61 (1987): 307-320. Janice Schultz took up the issues in several articles including: "Is-Ought: Prescribing and a Present Controversy," Thomist 49 (1985): 1-23; “'Ought'-Judgments: A Descriptivist Analysis from a Thomistic Perspective," New Scholasticism 61 (1987): 400-426; "Thomistic Metaethics and a Present Controversy," Thomist 52 (1988): 40-62; and "St. Thomas Aquinas on Necessary Moral Principles," New Scholasticism 62 (1988): 150-178. Peter Simpson has also contributed in "St. Thomas on the Naturalistic Fallacy," Thomist 51 (1987): 51-69; and in "Practical Knowing: Some Comments on Finnis and Aquinas," Modern Schoolman 67 (1990): 111-122. 


\section{THE EPISTEMOLOGICAL QUESTION}

The principles of practical reason, which Aquinas also calls the precepts of natural law, specify goods to be pursued by actions. These Grisez and Finnis call the basic goods. Did Aquinas think that certain principles of practical reason could be inferred from certain factual judgments about human nature and natural inclinations? Grisez and Finnis are brisk and emphatic in their insistence that Aquinas did not think such an inference could be made. ${ }^{6}$ Is this correct?

Let us consider first Summa theologiae 1-2.94.2. This passage is the only one which Grisez treats extensively, and from which he develops his interpretation. Since it is, as it were, Grisez's chosen field of battle, we should expect to find strong support for his view here. But I believe McInerny provides a more natural reading of the article.

In the corpus of this article, after saying that practical reason is analogous to theoretical reason, and that the first principle of theoretical reason, the principle of non-contradiction, is based on its first ratio, the ratio of being, Thomas writes:

And thus the first principle in practical reasoning is the one based upon the ratio of the good, which is: good is 'that to which all things are naturally inclined'. Therefore this is the first precept of the law, that good is to be done and pursued, and evil is to be avoided.?

In this passage, then, Thomas tells us that the formula which expresses a subject's intellectual grasp of the ratio of good is 'that to which all things are naturally inclined'. Since this seems to suggest that the understanding of the good is as the object of natural inclination, it appears that precepts stating basic goods for humans can be inferred from judgments about our natural inclinations. Thus this passage appears, at least prima facie, to undermine Grisez's interpretation.

Grisez, of course, offers an alternative reading of this passage. He distinguishes two senses of 'good'. There is, he concedes, a descriptive sense of 'good' according to which the good is simply the end of some

6. Grisez, "First Principle," p. 195; Finnis, Natural Law and Natural Rights, p. 33.

7. Thomas Aquinas Summa theologiae 1.94.2. As with all the citations from Aquinas in this paper, the translation is mine. The edition of the Summa used is the collation of the Piana and Leonine editions (Ottawa: Commissio Piana, 1953-). In this passage, the quotation marks and italics are mine. 
natural tendency. As he writes, "for each active principle the end on account of which it acts is a good for it. . . " Hence, we can say that blooming in spring is good for roses, and they ought to do so..$^{9}$ But, he insists, "to get moral principles from metaphysics, it is not from the 'is' of nature to the 'ought' of nature that one must go." 10 The good and ought relevant to practical reason and natural law are the normative senses; in this sense 'good' is not meant as the object of a natural tendency. Grisez, then, sharply distinguishes the normatively good from the descriptively good.

About the passage in question, Grisez writes:

This formula [i.e., 'bonum est quod omnia appetunt'] is a classic expression of what the word 'good' means. Of course, we often mean more than this by 'good', but any other meaning at least includes this notion. ${ }^{11}$

It is not clear, however, just what Grisez thinks the grasp of the ratio of good is. He may be suggesting that the sense of 'good' under discussion in Summa theologiae 1-2.94.2 is some generic notion which includes both the descriptive and normative notions as species. Alternatively, Grisez might be suggesting that the notion is initially simply the vague notion of someone who has as yet failed to distinguish the descriptive and normative notions. If he is suggesting the former, he must give us some reason to believe that Aquinas recognizes such a generic notion-but he does not do this. If he is suggesting the latter, he must explain how a correct apprehension of the principles of practical reason can be based upon a vague understanding of the intelligibility of the good-but neither does he do this.

It is difficult to extract from Grisez any clear interpretation of this passage in Summa theologiae 1-2.94.2 about the ratio of good. His failure to produce a clear interpretation of this passage is not, I believe, due simply to careless writing. It is due, rather, to an incompatibility between key tenets of Grisez's reading of Aquinas and what Aquinas actually says about our understanding of the good.

In the corpus of Summa theologiae 1-2.94.2 Aquinas is concerned with a certain order among what is apprehended by the intellect. ("Of

8. Thomas Aquinas Summa theol. 1.94.2.

9. Thomas Aquinas Summa theol. 1.94.2.

10. Thomas Aquinas Summa theol. 1.94.2.

11. Grisez, "First Principle," p. 178. 
the things which enter into our apprehension of anything, a certain order is found.") Regarding the principles of practical reason, that which falls first in this order is the grasp of the ratio of good as 'that to which all things are naturally inclined', which grasp we have been discussing. Based upon this grasp is the first principle of practical reason, 'Good is to be done and pursued and evil avoided'. ("The first principle in practical reasoning is based on the ratio of good.") Thirdly, the subordinate principles of practical reason are based upon the first principle. ("On this [first precept of the law] is based all other precepts of the natural law.")

It is not entirely clear just what Aquinas has in mind when he speaks of "a certain order" which is found among "the things which enter into our apprehension." The order may be that by which people ordinarily become aware of the principles. Alternatively, it may be an order of explanation; that is, though what is prior may not be known before what is posterior in the order, nevertheless we explain what is posterior by reference to what is prior. ${ }^{12}$ But, however this order is to be understood, it does seem clear that whatever sense good has in the first principle and subordinate principles, it is that which is apprehended in the initial grasp of the ratio of good. If this were not so, it is hard to see how the subordinate principles could be "based upon" the grasp of the ratio of good.

According to Grisez, however, the sense of 'good' in the subordinate principles of practical reason is of the normatively good. In this sense, Grisez emphasizes, 'good' is not understood as what is the object of some natural inclination, for that is the understanding of the descriptively good. But then it seems clear that the sense 'good' has in these subordinate principles is not "that to which all things are naturally inclined." Therefore it seems that Grisez is forced to accept some change in the sense of 'good' between the initial grasp of the ratio of good and the formulation of the subordinate principles of practical reason.

McInerny, on the other hand, does not recognize a distinction between the descriptively good and the normatively good. He holds that the ratio of good is the ratio under which we desire all we desire. For McInerny, then, the grasp of the ratio of good can be a grasp of

12. An argument in subsequent pages implies that it is best understood as an order of explanation. 
'that to which all things are naturally inclined', if this is taken as the ratio of their inclination. This understanding would be what is presupposed by practical reason. And it would lead us, as McInerny suggests, to a consideration of our natural inclinations and of what is perfective of human nature. This consideration would then lead us to the fundamental precepts of the natural law. And this reasoning seems to accord with that outlined in the corpus of Summa theologiae $1-2.94 .2$.

I have argued, then, that Grisez must read into Summa theologiae $1-2.94 .2 \mathrm{c}$ a shift in the sense of 'good' which Aquinas does not acknowledge, and that consequently Grisez's reading of the passage is more forced and unnatural than McInerny's alternative, and perhaps other alternatives as well. But although this conclusion may weaken Grisez's position, it does not wholly undermine it: Grisez can argue that his interpretation is unavoidable in light of other considerations, and thus, all things considered, it is superior to the alternatives. So we are led to ask what other support Grisez and Finnis offer for their reading. And the answer to this is clear: it is that Thomas says that the principles of practical reason are immediate, indemonstrable and per se nota. As Grisez writes, these principles "are not derived from statements of fact. They are principles. They are not derived from any statements at all. . . They are underivable."13 This also seems to be Finnis's primary argument: "Aquinas asserts as plainly as possible that the first principles of the basic forms of good and evil, which specify the basic form of good and evil and which can be adequately grasped by anyone of the age of reason . . . are per se nota (self-evident) and indemonstrable." 14 Let us say that a proposition, $p$, is epistemically basic for a subject, $S$, if $S$ believes $p$, but $S$ does not believe $p$ on the basis of any other proposition $S$ believes. Grisez and Finnis's point here is that if certain propositions are said to be principles which are per se nota and indemonstrable, then, in the normal case at least, they are epistemically basic for a normal subject. This seems to be Grisez and Finnis's primary argument in support of their position on the epistemological question.

13. Grisez, "First Principle," p. 195. In a more recent defense of his position, Grisez repeats and reaffirms this argument. See Grisez, "Natural Law and Natural Inclinations."

14. Finnis, Natural Law and Natural Rights, p. 33. 
I will try to show that this argument of Grisez and Finnis is based upon a common misunderstanding of Thomas's view of a science and scientific demonstration. ${ }^{15}$ Aquinas's most extensive discussion of the nature of scientific demonstration is found in his commentary on Aristotle's Posterior Analytics. When we turn to Aquinas's Aristotelian commentaries, however, we run into the thorny and controversial question of whether and to what extent we can attribute to Aquinas the views he attributes to Aristotle. ${ }^{16} \mathrm{My}$ own view is close to Chenu's, who says that a medieval commentator such as Aquinas is presumed to take the contents of the text as his own unless he says otherwise. ${ }^{17}$ In what follows, however, although I will quote Aquinas's Aristotelian commentaries as indicating his own view, I will add, in footnotes or in the text, a place where Aquinas asserts or implies the doctrine in question in his own work.

The propositions which are principles of a science are, as Thomas frequently notes, "immediata, indemonstrabiles et per se nota." As he writes, "any proposition whose predicate is contained in the ratio of the subject is immediate ['immediata'] and self-evident ['per se nota']. . .."18 He seems to have several interrelated points in mind here. A proposition of the form ' $A$ is $B$ ' is immediate if there is no further middle term, $B^{*}$, which one can employ in a demonstrative syllogism to demonstrate the inherence of $B$ in $A$. That is, ' $A$ is

15. Even a persistent critic of many features of the Grisez-Finnis position, Janice Schultz, accepts this point that per se nota propositions are epistemically basic for the normal subject, though it presents rather serious problems for her. See Schultz, "Necessary Moral Principles."

16. See Jean Isaac, "Saint Thomas interprète des oeuvres d'Aristote," in Scholastica Ratione Historico-Critica Instauranda: Acta Congressus Scholastici Internationalis Romae anno sancto 1950 celebrati (Rome: Pontificium Athenaeum Antonianum, 1951), pp. 355-363; Marie-Dominique Chenu, Toward Understanding Saint Thomas, trans. A.-M. Landry and D. Hughes (Chicago: Henry Regnery, 1964); Joseph Owens, "Aquinas as Aristotelian Commentator," in St. Thomas Aquinas 1274-1974: Commemorative Studies, ed. Armand A. Maurer (Toronto: PIMS, 1974) 1:213-238; Mark Jordan, "Thomas Aquinas's Disclaimers in the Aristotelian Commentaries," in Philosophy and the God of Abraham: Essays in Memory of James A. Weisheipl, O.P., ed. R. James Long (Toronto: PIMS, 1991), pp. 99-112.

17. Chenu, Toward Understanding Saint Thomas, pp. 207-208.

18. Thomas Aquinas Expositio libri Posteriorum 1.5, Leonine Opera omnia $1 * / 2$ (Rome: Commissio Leonina and Paris: J. Vrin, 1989), p. 25, lines 116-118. Compare Summa theol. 1.2.1. 
$B^{\prime}$ is immediate if there is no proper demonstrative syllogism of the form:

$A$ is $B^{*}$
$B^{*}$ is $B$
$A$ is $B$

And since there is no further middle term $B^{*}$, there is no demonstrative syllogism which proves that $A$ is $B$, and this proposition is indemonstrable. Finally, since there is no more ultimate middle term, it is thought that the predicate $B$ is "contained in" the ratio of $A$, and so the proposition ' $A$ is $B$ ' can be known by anyone who fully understands the rationes involved. That is, it can be known per se, or, as Grisez and Finnis say, it is self-evident. The three termsimmediate, indemonstrable, and self-evident-are, it is important to note, co-extensive terms for Aquinas.

Grisez and Finnis realize that not all immediate, self-evident propositions are self-evident to us. Although it is true that for any such proposition a full grasp of the ratio of the subject is sufficient for seeing that the predicate is contained in it and thus that the proposition is true, such a grasp of the ratio of the subject may be beyond us. This may be so even when we in some sense understand the proposition, yet fall short of a complete understanding which enables us to see that the proposition is true. In such cases, the proposition is self-evident in se or secundum naturam, but not quoad nos. The most extreme cases of such a disparity between what is self-evident in itself and to us are found in theology. That God exists is self-evident in itself, but not to us:

This proposition, 'God exists', is self-evident in itself, because the predicate and subject are identical; for God is his own existence. . . But because we do not possess scientific knowledge of God with respect to what he is, he is not self-evident to us. Rather, [the proposition 'God exists'] needs to be demonstrated through things which are better known to us, and less known according to nature, namely, through God's effects. ${ }^{19}$

So Thomas distinguishes between what is self-evident "in itself" ("in se") and "with respect to us" ("quoad nos"), and these are by

19. Thomas Aquinas Summa theol. 1.2.1. 
no means co-extensive; though all of what is self-evident to us is self-evident in itself, some of what is self-evident in itself is not evident to us. The proposition 'God exists' is an example of an immediate, indemonstrable, self-evident principle which is not evident to us. As the passage just quoted indicates, such a proposition, though it is indemonstrable, nevertheless admits of demonstration by us. The resolution of this paradoxical claim is found, of course, in distinguishing two sorts of demonstration. A self-evident principle does not admit of demonstration propter quid, which, as we see below, is required from scientific demonstration. It does admit of, and can come to be known by, demonstration quia, which is demonstration from effect to cause. Thomas writes:

There are two kinds of demonstration. One is through the cause [to the effect], and it is called a propter quid demonstration: and this is [a demonstration] which moves from things which are prior simpliciter. The other is through the effect [to the cause], and it is called a demonstration quia: and this is [a demonstration] which moves from those things which are prior with respect to us; for when an effect is more manifest to us than its cause, we move from the effect to knowledge of the cause. . . Hence, due to the fact that God's existence is not something self-evident with respect to us, it is demonstrable from effects better known to us. ${ }^{20}$

The propositions which concern us are not theological, but the principles of practical reason. Finnis says that Aquinas is "regrettably obscure" on, among other things, the question of to whom the principles are self-evident. ${ }^{21}$ Yet, as we have seen above, from Thomas's claim that the principles of practical reason are self-evident and indemonstrable, Grisez and Finnis want to infer that he thinks they are epistemically basic for the ordinary subject who is capable of rational moral judgments. Therefore, they must suppose that, unless there is some more or less clear indication to the contrary, then in the nontheological sciences self-evident means self-evident quoad nos as well as in se. This supposition would be very plausible if Thomas thought the demonstrative structure of these sciences was epistemological. That is, the claim would be plausible if Thomas thought that the order of demonstration in the various sciences reflected the order in

20. Thomas Aquinas Summa theol. 1.2.2.

21. Finnis, Natural Law and Natural Rights, p. 51. 
which one ${ }^{22}$ comes to know the various propositions of the science. This may seem a very plausible way to think of the demonstrative structure of a science. I want to argue, however, that this is clearly not the way Aquinas thought of the demonstrative structure of a science, and thus that Grisez and Finnis's supposition that self-evident principles can generally be supposed to be self-evident quoad nos is quite unfounded.

One possesses demonstrative knowledge when one knows a proposition as the conclusion of a demonstrative syllogism. ${ }^{23}$ A demonstrative syllogism is not just any valid, sound syllogism, but one which Aristotle characterizes as follows:

... it is necessary for demonstrative understanding in particular to depend on things which are true and primitive and immediate and more familiar than and prior to and explanatory of the conclusion (for in ths way the principles will also be causal to what is being proved). 24

According to Aristotle, then, a key requirement of a demonstrative syllogism is that the premises refer to the cause and the conclusion refers to the effect. Aquinas in his own work says that "scientia" can be gained by a demonstration quia, one which moves from effects to cause. ${ }^{25}$ However, it seems clear that this is scientific knowledge in a secondary or deficient sense, for such an apprehension does not proceed from principles which are per se nota or known by a higher science. ${ }^{26}$ For science simpliciter, demonstrations must be propter quid; they must proceed from causes which are prior simpliciter. 27 This

22. The knower in question may either be the one who first discovered truths of the science, the student who learns them, or both the discoverer and the student.

23. "Scientific knowledge (scire) seems to be nothing other than 'to understand' the truth of some conclusion 'through demonstration'" (Thomas Aquinas Expos. Post. 1.4 [Leonine 1*/2:20.142-144]). Compare, "Scientia causes the intellect to assent through vision and understanding of first principles" (Summa theol. 1.12.13.ad 3).

24. Aristotle Posterior Analytics 1.2 (71b20-23), trans. Jonathan Barnes, in The Complete Works of Aristotle, ed. Barnes (Princeton: Princeton University Press, 1984) $1: 115$, with modifications.

25. Thomas Aquinas Summa theol. 2-2.1.5.

26. Thomas Aquinas Summa theol. 1.1.2. Aquinas follows Aristotle in distinguishing between scientific knowledge in its full sense or simpliciter and various deficient or secundum quid forms of it. See Aristotle Posterior Analytics 2 and Thomas Aquinas Sent. Post. Anal. 1.4.

27. Thomas Aquinas Summa theol. 1.2.2. 
requirement that scientific demonstrations are demonstrations propter quid implies that the demonstrative structure of a science is not epistemological, but reflects the real causal order. Aquinas realized, for example, that the position of the moon caused high and low tide, and thus, on this view of demonstrative science, the fact that the tide is high must be demonstrated from the fact that the moon is in a certain position. But, clearly, we do not come to know that it is high tide by inferring it from our beliefs about the moon's position; knowledge of the moon's causal influence was no doubt subsequent to the awareness of high tide.

This issue is somewhat complicated, however, by the fact that Aristotle and Aquinas held that epistemological considerations were relevant to a demonstrative syllogism, albeit not in that the former determined the structure of the latter. In the passage just quoted, Aristotle says that premises must be "better known" than conclusions, and the point of this stipulation becomes clear later in the text. For a perfect demonstrative syllogism, it seems that not only must the demonstration be from cause to effect, but our knowledge of the cause must itself be the cause of our knowledge of the effect. ${ }^{28}$ That is, although we initially come to know causes through effects, the goal of scientific inquiry is, as it were, 'to restructure' our beliefs so that we come to know effects through causes.

However this 'restructuring' is to go, it seems clear that the stipulation that the principles, which describe the causes, are known better than and prior to conclusions, which describe effects, expresses an ideal and not the norm for initial discovery in a science. God knows effects through causes, ${ }^{29}$ but for the weaker intellects of human beings, in a very large number of cases, our knowledge of conclusions of a science is prior to, better known than, and the cause of our knowledge of its principles. Thus the principles of a science are always intrinsically self-evident, but not to us:

And because prior and better known are said in two ways (viz., with respect to us and according to nature) the Philosopher consequently says

28. Aristotle Posterior Analytics 1.2 (72a25-33). Compare Thomas Aquinas Summa theol. 1.12.13 ad 3 and 1-2.51.2.

29. "God [sees] his effects in himself, which is [to see them] in their cause...." (Summa theol. 1.14.7). 
that those things from which demonstration moves are prior and better known simpliciter and according to nature, and not to us. ${ }^{30}$

Consequently, Aquinas writes, in the normal course of much of scientific inquiry, the immediate and intrinsically self-evident principles are demonstrated from non-immediate, intrinsically less evident conclusions of the science:

In the acquisition of scientific knowledge principles and elements are not always prior, for sometimes from sensible effects we arrive at knowledge of principles and intelligible causes. ${ }^{31}$

Such a demonstration is, of course, a demonstration quia. Thomas, following Aristotle, continues to hold that, though the principles may initially be known through effects, one strives for the ideal of knowing effects through causes, and achieving this ideal often requires a certain restructuring, as it were, of one's system of beliefs. ${ }^{32}$ But in whatever way this restructuring is to be achieved, it seems clear that the way in which principles are known according to this ideal is certainly not the way they are first known by a subject.

If the preceding is correct, then we cannot straightforwardly infer from the fact that Aquinas says that certain principles are immediate and self-evident that they are self-evident quoad nos, and thus epis-

30. Thomas Aquinas Expos. Post. 1.4 (Leonine 1*/2:21.245-9). Compare, Summa theol. 1.2 .2 .

31. Thomas Aquinas Summa theol. 1.85 .8 ad 1. See also my "Aquinas on the Veracity of the Intellect," Journal of Philosophy 88/11 (1991): 623-632, especially pp. 629632. I discuss Aquinas's account of how our apprehension of natural essences arises initially from a grasp of merely accidental properties apparent to sense perception.

32. In several passages Aristotle and Aquinas wrestle with the question of how this restructuring might be carried out. As Aquinas writes, "in the completion of scientific knowledge, the scientific knowledge of the effect always depends on knowledge of principles and elements since, as the Philosopher says..., we do not think we know something scientifically until we can make principles manifest in light of their causes" (Summa theol. 1.85.8 ad 1). This is perhaps plausible when we can come to have more immediate knowledge of a cause we initially knew by inference from effects. Neil Armstrong would have achieved such knowledge if an eclipse had occurred while he was standing on the moon. Barring lunar travel, it is difficult to see how this cause could ever be better known if someone were, as Thomas and Aristotle certainly were, restricted to hypothetical inference from effects observable from earth. This is precisely the problem Aristotle struggles with in Posterior Analytics 1.13, but with dubious results. 
temically basic in the normal case for a normal subject. In the case of very obvious and fundamental tautologies, such as the principle of non-contradiction, he certainly does think these are self-evident to all. But in the case of at least many and perhaps most principles of sciences, we must move from what is most knowable to us to what is most knowable in itself, and so the immediate principles are initially known inferentially. But if this is so, the central argument of Grisez and Finnis regarding the epistemological question collapses. In the absence of some further evidence from the texts of Thomas, we cannot suppose that the principles of practical reason-or any other science for that matter-are, at least initially, epistemically basic for a subject.

There seems to be another consideration which, less overtly but perhaps just as powerfully, motivates Grisez and Finnis's view. In a reply to McInerny they discuss the move from descriptive to normative claims. Generally when Grisez and Finnis discuss this, they ask whether there is a "licit inference," 33 or about whether ought can be derived from is. ${ }^{34}$ Here they say, "Our point . . . was that there can be no valid deduction of a normative conclusion without a normative principle, and thus the first practical principle cannot be derived from metaphysical speculation." 35 They move without explanation from a question of rational inference to a question of deduction. The question of the inference or derivation of certain propositions from others is a question about epistemically rational inference, one form of which is logical deduction. But Grisez and Finnis's unexplained shift from speaking of inference generally to deduction suggests that they see the former is restricted to the latter in this case. If this is granted, then Grisez and Finnis are perhaps right that normative conclusions cannot be derived from descriptive premises, but why should we suppose that Aquinas would recognize such a restriction? It makes sense within the tight strictures of a Humean epistemology, and thus it is no surprise that Hume was the one to announce that 'is' cannot be derived from 'ought'. But there is no reason to suppose that Aquinas's epistemology was Humean. And thus there is no reason to suppose that the derivation of normative from descriptive claims must be restricted to logical deduction.

33. Finnis, Natural Law and Natural Rights, pp. 33-36.

34. Grisez, "First Principle," p. 194.

35. Grisez and Finnis, "Basic Principles," p. 24. 
I conclude that Aquinas did think that normative judgments, and indeed some principles of practical reason, can be inferred from certain judgments about human nature and human inclinations. This interpretation gives us a more natural reading of Thomas's discussions on the principles of practical reason, and Grisez and Finnis's arguments against such a reading are not compelling.

\section{THE CONCEPTUAL QUESTION}

In addition to the epistemological question, there is a conceptual question about the good. Is being desirable, being the object of natural inclinations, constitutive of the concept of good for Aquinas? McInerny seems to answer this question affirmatively, while Grisez and Finnis respond negatively. Although I sided with McInerny on the epistemological question, I think Grisez and Finnis are nearer the truth on this question.

The question to be addressed must be formulated more precisely. First of all, the above formulation asks whether being desirable is constitutive of being good, but 'desirable' is ambiguous. Let us introduce some distinctions and corresponding labels. Let us call something 'factually desirable' if it is such that it is either what an agent thinks will satisfy his desires, or what will in fact do so. We can divide this genus into two species. Of the factually desirable objects or states of affairs, let us call those 'merely factually desirable' which an agent thinks will satisfy his desires, though they would not, if attained, in fact do so. And let us call those 'genuinely factually desirable' which are such that, if attained, would in fact satisfy the agent's desires, whether or not the agent realizes this.

For both sorts of the factually desirable, desirability is a relational attribute; it is an attribute something has insofar as it bears a relationship to an agent with certain desires and beliefs, or, at least, certain dispositions to desire and believe. These two are the only senses of 'desirable' which McInerny considers or would accept. ${ }^{36}$ It will be helpful, though, to introduce another sense of 'desirable'

36. In McInerny's terminology, the factually desirable is called the desirable ${ }_{1}$, and the genuinely factually desirable is called the desirable 2 . 
to accord with Grisez and Finnis's understanding of Thomas's basic goods. According to them, these goods are goods for humans because human beings, given their natural inclinations, have a certain affinity to them; but their goodness does not consist in the fact that humans have such an affinity. It is rather a feature some things have independently of whether humans in fact desire them. Such goods are, according to Grisez and Finnis, worthy of desire intrinsically, whether or not they are factually desirable, and whether merely or genuinely so. Let us say that an object which is worthy of desire in this non-relational sense is intrinsically desirable. McInerny's view seems to be that being genuinely factually desirable is constitutive of the concept of good, while Grisez and Finnis seem to think that only being intrinsically desirable is.

A second needed refinement of our question regards the terms 'constitutive' and 'concept'. Although these terms are taken for granted by recent philosophers, it is not obvious how they are to be translated into Aquinas's terminology. For Aquinas, the essence or quiddity of a thing is what makes a thing the sort of thing it is. ${ }^{37}$ In the primary senses of the terms, only substances have an essence or quiddity, and the essence is primarily the substantial form. ${ }^{38}$ The essence is the principle of intelligibility of the thing, and as intelligible structure (which is the substantial form abstracted from the individuating conditions of matter) it is called the intelligible species or ratio. ${ }^{39}$ This ratio is expressed by a definition..$^{40}$ In his commentary on Aristotle's Metaphysics Aquinas says that although only substances have an essence or quiddity and a definition in the primary senses of these terms, in a secondary and analogous sense things which are not in the category of substance, such as good, have an essence or quiddity and definition. ${ }^{41}$ In what follows, then, I will speak of the essence or

37. See, for example, De Ente et Essentia 1 and Sent. lib. Metaphysicorum 7.3, ed. R. Spiazzi (Rome: Marietti, 1950), no. 1303.

38. Thomas Aquinas Sent Metaph. 7.3 (Spiazzi nos. 1324, 1327).

39. Thomas Aquinas Expositio Super Librum Boethii De Trinitate 5.2; Summa theol. 1.85.1, corpus ad 1 , ad 2 .

40. Thomas Aquinas Expositio libri Peryermenias 1.2 in the Leonine Opera omnia $1 * / 1$ (Rome: Commissio Leonina and Paris: J. Vrin, 1989), pp. 10-11, lines 89-112; Sent. Metaph. 7.7 (Spiazzi no. 613).

41. Thomas Aquinas Sent. Metaph. 7.4 (Spiazzi nos. 1331, 1335, 1337, 1355). 
quiddity of good and its ratio and definition in this secondary and analogous sense of these terms.

We can now reformulate our question as follows: Is being an object of natural inclination, in the sense of being genuinely factually desirable, part of the quiddity, or essence, or ratio of good for Aquinas? Let us label one who answers this question affirmatively an essentialist. As said above, though I believe McInerny seems to hold an essentialist position, his view is not elaborated. One who does explicitly embrace a version of essentialism and elaborates it is Ronald Duska. 42

Duska emphasizes De veritate 21, articles 1 and 2 in his interpretation of Aquinas. He claims that there we find "a definition of the good as well as explanations of this definition." 43 That is, he explains, in this question Aquinas gives us "necessary conditions for calling something good." 44 Duska quotes two passages in this regard. (He actually quotes Aquinas in an English translation which I find problematic and which does not accord with the terminology I have adopted in this paper. Thus I provide my own translation along with Aquinas's Latin.) These are:

It is to be said that, since the ratio of good consists in this, that something is perfective of another as an end, whatever is found to have the ratio of an end also has the ratio of good. Two things are of the ratio of an end: (1) it is naturally inclined to or desired by those who have not yet attained the end, or (2) it is enjoyed, and, as it were, enjoyable, by those who participate in the end.

Dicendum quod cum boni ratio in hoc consistat quod aliquid sit perfectum alterius per modum finis, omne illud quod invenitur habere rationem finis

42. Ronald Duska, "Aquinas's Definition of Good: Ethical-Theoretical Notes on De veritate, Q. 21," Monist 58 (1974): 151-162. Ironically, John Finnis refers us to Duska's article for clarification about "the relation between the desired, the desirable, and the perfective in Aquinas's notion of good" (Natural Law and Natural Rights, p. 79). Others, as well as myself, find this confusing (see also Janice Schultz, "Thomistic Metaethics and a Present Controversy"). For Duska's reading would not support but undermine Finnis's claim that "for one who considers knowledge to be a good, the true expression of his opinion and attitude is not 'it is good because or in so far as I desire it', but 'I desire it because and in so far as it is good' " (Natural Law and Natural Rights, p. 70).

43. Duska, Natural Law and Natural Rights, p. 152.

44. Duska, Natural Law and Natural Rights, p. 152. 
habet et rationem boni. Duo autem sunt de ratione finis: ut sit scilicet appetitum vel desideratum ab his quae finem nondum attingunt, et ut sit delectum et quasi delectible $a b$ his quae finem participant. . . ${ }^{45}$

Primarily and principally, therefore, a being is called good which is perfective of another as an end.

Sic ergo primo et principaliter dicitur bonum ens perfectivum alterius per modum finis. 46

Duska discusses what he sees as "two elements in this definition... (1) the notion of good as something perfective of another and (2) the notion of good as an end." 47 He comments on the second "element," saying:

According to the text there are two simple criteria for determining whether something is an end: (1) "It must be sought [appetitum] or desired by things which have not yet attained the end," and (2) "it must be loved [dilectum] by the things which share the end, and be, as it were, enjoyable [delectible] to them. ${ }^{48}$

We find in Duska's Aquinas what I will call a dual component view of the essence or ratio of good. The essence or ratio of good for something of a certain kind consists of both the notion of being perfective for that sort of thing and the notion of being an end, which is just to be desired or enjoyed by individuals of that kind. As he points out, this second component requires actual desiring and, if attained, actual enjoyment. ${ }^{49}$ Duska's position, then, is an essentialist one which sees being the object of natural inclinations of certain creatures, being genuinely factually desirable for them, as one component of the essence or ratio of good for creatures of that kind; being perfective for creatures of that kind is the other

45. Thomas Aquinas Quaestiones disputatae de veritate 21.2, in Leonine Opera omnia 22 (Rome: Editio di San Tomasso, 1975), p. 596, lines 61-69.

46. Thomas Aquinas De verit. 21.1 (Leonine 22: 594.207-209).

47. Duska, Natural Law and Natural Rights, p. 153.

48. Duska, Natural Law and Natural Rights, p. 153.

49. As Duska writes, "this criterion for an end of being desired, demands actual desiring" (Natural Law and Natural Rights, pp. 153-154, n. 10). 
component. ${ }^{50}$ There are some immediate and obvious problems with what Duska says. Firstly, it seems unwise to base an interpretation of Aquinas on the Quaestiones disputatae de veritate, one of his earliest works. ${ }^{51}$ If we find in the De veritate claims which are not repeated in, for instance, the Summa theologiae, it is probably because Aquinas came to believe the earlier formulations were vague, or misleading, or just plain wrong. But Duska does not cite later works. Secondly, Duska says that Aquinas gives a "definition" of good in the passage he quotes, though Aquinas does not speak of a definitio in this passage. Duska, however, does not mention what Aquinas does call a definitio, Aristotle's formula 'that to which all things are naturally inclined'. Thirdly, though Duska does say that though this "characterization" is not a proper definition in terms of genus and species, he calls it a definition because "if any characterization gives necessary condition, it seems to be some attempt to define." 52 But in saying this he conflates the essence of a thing and its proper accidents, which are not part of the essence but which may also be necessary attributes of things with that essence. Fourthly, Duska distinguishes (1) ends for beings which

50. The dual component view of the ratio of good seems to be the majority position presently, Grisez and Finnis not withstanding. It is found not only in McInerny and Duska, but in others as well. For example, Peter Simpson in a recent article, "St. Thomas on the Naturalistic Fallacy," writes: "[Good] involves reference to desire. . . . It expresses how that being, just as such a being, is a fulfillment and completion of whatever is directed to it as to an object of desire. Good expresses being along with the idea of end, goal or fulfillment" (p. 61). In interesting twists within this confusing area, Douglas Flippen separates the two components into two distinct senses of good, in "On Two Meanings of Good and the Foundation of Ethics in Aristotle and Aquinas," Proceedings of the American Catholic Philosophical Association 58 (1984): 57-59. Janice Schultz, on the other hand, sees the desire component as involving a relationship to a possible, rather than an actual, desire, in "Thomistic Metaethics and a Present Controversy." I do not think that either Flippen's or Schultz's view can be sustained, but I will not discuss them in this paper.

51. The De veritate consists of questions disputed during Aquinas's first Parisian regency (1256-59), immediately after the completion of the commentary on the Sentences of Peter Lombard and his inception in theology. Questions 21 and 22 were probably disputed during the third year of that regency, 1258-59. For a discussion of the dating, see James A. Weisheipl, Friar Thomas D'Aquino: His Life, Thought, and Work, rev. ed. (Washington: Catholic University of America Press, 1983), pp. 123125, with the summary on pp. 362-363.

52. Duska, Natural Law and Natural Rights, p. 152, n. 5. 
desire and enjoy, such as humans, and (2) ends which may be ends simply in virtue of being the termination of a natural process, such as becoming an oak is the end for an acorn. He then writes that "in the passage cited [De veritate 21.2] the primary use of the word 'good' is the use when [sic] it is applied to beings who desire and enjoy"53 such as human beings. But Aquinas speaks of what is desired as "appetitum," and he clearly holds that all creatures, living and nonliving, have "appetitus." Indeed, in the very sentence of De veritate 21.2 from which Duska takes the passage he quotes Aquinas illustrates the "desire for" and "enjoyment of" an end with the example of a rock which moves toward and ultimately rests at the center.

There are serious problems with Duska's essay, and anyone wishing to defend Duska's view would have to address them. However, I will assume that a more careful expositor of the dual component view can handle them and will ask whether, these problems aside, the dual component interpretation is defensible. I will argue that although Aquinas sees that there is a close connection between being the object of natural inclination and being good, the former cannot be part of the ratio of the latter.

If the dual component view of the ratio of good is correct, then being good is, at least partly, a relational attribute. The fact that $X$ is good is partially dependent on $X$ 's relation to other beings, viz., to beings with a natural inclination to $X$ or the capacity to enjoy $X$. If some thing, $X$, is good for humans, then it is part of the ratio of good that there must be a human agent, $A$, who desires $X$ or would enjoy $X$ if $X$ were attained. The problem for the dual component interpretation of Aquinas is that this does not seem to accord with much of what Aquinas wrote.

Let us recall, first of all, the earlier discussion of scientific demonstration and its principles. There I argued that one may come to know some principles of a science by inferring them from other propositions not themselves principles. The fact that they are principles does not mean they must be epistemically basic for a subject. Although this is so, it is nevertheless clearly Aquinas's position that the principles describe what is the ultimate cause in a certain field. They are therefore ultimate in the order of explanation in demonstrative science. If 'A

53. Duska, Natural Law and Natural Rights, p. 157. 
is $B^{\prime}$ is a principle of science, then there is no further middle term, $B^{*}$, with which we can demonstrate that $B$ inheres in $A$. Rather, if ' $A$ is $B^{*}$ ' is a claim within that field of science, $B^{*}$ 's inherence in $A$ is demonstrated with the principle ' $A$ is $B$ ', or with some other principle, as a premise.

In the Summa theologiae the principles of practical reason include propositions such as 'Knowledge is good' and 'Procreation and rearing of children are good'. Consider a principle such as these. If the dual component view is correct, then procreation is good only if it bears a certain relationship to an agent with certain desires or dispositions to enjoy, for part of what it is to be good is to be the object of desire and enjoyment. Being good is, therefore, partially a relational attribute of procreation. For any such relational attribute, its inherence can be explained with reference to the relata and the relationship; that Bill Clinton is the choice of the people, for example, can be explained with reference to the people and their choice. Similarly, according to the dual component view, it would seem that the goodness of procreation and rearing can be explained with reference to the desires and dispositions to enjoyment of human agents. Hence, the following demonstrative syllogism seems possible:

Procreation is perfective and an object of desire.

What is perfective and an object of desire is good.

Procreation is good.

But if this is so, then the proposition 'Procreation is good' would not be, as Thomas clearly claims it is, an immediate and per se nota principle of practical reason. The same would be true for all the other principles of practical reason.

There are also problems for the dual component interpretation arising from the De veritate itself. In an article of De veritate q. 21, Aquinas asks: "Are all things good by the First Goodness?" There Aquinas tells us how a certain sort of Platonic account of good and goodness can be sustained, for the First Goodness, God, is in a certain way the principle of all good things. He writes:

If the First Goodness is the efficient cause of all goods, it must be that he informs all his effects with his likeness; and so each thing is called good through likeness to the highest good in the way of an inherent form 
infused into it, and further through the First Goodness in the way of the exemplar and efficient cause of all created goods.

Thus God, the first and highest good, is the principle of all goods insofar as he infuses in all good things the form which is the likeness of his goodness, and thus God is the exemplar and efficient cause of their goodness. Here Aquinas only speaks of God being the principle of good things insofar as he is the efficient cause and exemplar of their intrinsic forms. However, if the dual component view is correct, God could only be the principle of things being good if he were also the principle of the inclinations of other creatures for the good thing. Aquinas does not mention such inclinations in this article.

Furthermore, in De veritate 22.1 Thomas addresses the question: "Utrum omnia bonum appetunt." It is perhaps obvious that he is not asking whether there is some one thing which is good; the question should not be translated: "Do all things desire the thing which is good?" Rather, as he writes in response to an objection in this article, "when one says 'all things are naturally inclined to good,' the good need not be confined to this or that; it is, rather, to be taken in a general sense, because each thing is naturally inclined to the good naturally fitting to it." 54 Thus, he is asking in this article whether all things are naturally inclined to good. He asks, more precisely, whether they are inclined to the good which is fitting to the sort of creature they are; more simply, whether they are naturally inclined to their good.

Thomas begins his respondeo by answering in the affirmative, both for creatures having cognitive awareness, and for those lacking it. After mentioning a contrary view of ancient philosophers and offering an Aristotelian response, Aquinas goes on to explain how it is that all things are naturally inclined to what is good. A thing may be ordered to something in one of two kinds of ways: (1) a creature with some cognitive awareness of its end may be ordered of itself to its end, as a human being moves to the place she wishes to be; (2) a creature may be directed to its end by another, and this may be so even if it lacks cognitive awareness of its end, as an arrow which is directed to its target by an archer. Among cases of kind (2), the direction may come about ( $2 a$ ) violently, which occurs when the

54. Thomas Aquinas De verit. 22.1 ad 4. 
creature has no form in virtue of which there is a natural inclination to the end, as when a rock is thrown upwards. Alternatively, it may come about ( $2 \mathrm{~b}$ ) naturally, which occurs when the one directing the thing instills a form in virtue of which it is naturally inclined to its end, as when a rock is given a natural inclination to downward movement and moves downward. Non-cognitive, natural things have instilled in them forms in virtue of which they are naturally inclined to their proper ends. Although Aquinas does not emphasize it in this article, this is also true for creatures with cognitive awareness of ends, such as human beings, for they also have natural inclinations to their proper ends instilled by God, who is the first mover. ${ }^{55}$ What is naturally inclined to something is naturally inclined to that thing because of what the one who guides or directs it by instilling a form wills. So all natural things are naturally inclined to that to which God wills them to be inclined. Thomas then concludes the main argument of the article:

Since God has no other end of his will but himself, and since he is the essence of goodness, it must be that all other things are naturally inclined to good. ${ }^{56}$

The main argument of the article that all things are naturally inclined to their good seems to be more or less the following:

(1) Whatever are the objects of natural inclination are what God wills them to be.

(2) The end of God's will is God.

(3) God is the essence of goodness.

(4) The end of God's will is the essence of goodness, goodness itself.

(5) God wills for each creature what is good for that creature. ${ }^{57}$

55. See, for example, Thomas Aquinas De verit. 22.1 ad 6 .

56. Thomas Aquinas De verit. 22.1.

57. Only premise (5) is not explicitly in De verit. 22.1 or does not follow obviously from what is explicitly stated there. Yet it seems that it must be an implicit premise, for otherwise Aquinas could not move from the claim that God wills goodness itself (premise [4]) to the claim that creatures are naturally inclined to their respective goods (premise [6]). Moreover, it is Aquinas's express view elsewhere that in virtue of God's willing his own goodness he wills creaturely goods (see Summa contra Gentiles 3.8). 
(6) The objects of a creature's natural inclinations are what is good for that creature.

(7) Therefore, all creatures are naturally inclined to their good.

If this summary is roughly right, then Aquinas infers that creatures are naturally inclined to their good from the facts that (1) God determines the objects of creaturely natural inclinations, and (2) God wills that creatures are inclined to their good. Hence, on Aquinas's view, all things are naturally inclined to their good because of the benevolence of God who instills in a creature the natural inclination to its good. The dual component interpretation, however, cannot make sense of this claim. According to it the fact that something is good for a creature is partially constituted by the creature's inclinations, and so a thing's being good for a creature cannot be prior to that creature existing with certain inclinations. On the dual component view, Aquinas's claim in the De veritate 22.1 would be similar to the one that God wills that I most favor my favorite color, and so instills in me a disposition to favor my favorite color. But this is nonsense, of course, because nothing is my favorite color until I exist with certain dispositions to favor one color more than others, so God cannot instill in me inclinations to favor a color in light of what my favorite color is. Similarly, if the dual component interpretation is right, then it would be nonsense for Aquinas to say that God instills in creatures of a certain kind natural inclinations to something because God wills that they are naturally inclined to their good, for what is good for that sort of creature cannot be prior to such creatures having certain natural inclinations. But this is precisely what Aquinas claims. Hence, the dual component interpretation-or any interpretation which makes creaturely natural inclinations constitutive of what it is to be good for that creature-cannot be right.

Duska's dual component essentialist interpretation fails even with regard to the De veritate, where Duska believes it is strongly supported; it certainly cannot be sustained for Aquinas's later works in which there is less support. Moreover, I contend, the considerations just advanced show that no essentialist interpretation of Aquinas can succeed; that is, no interpretation which understands being the object of natural inclination as part of the essence or ratio of good can be sustained. The question then arises: what is the relationship between being good for a certain sort of creature and being the object of such creatures' natural inclinations? 
It is clear that Aquinas sees a close connection between being good and being the object of natural inclination, and in the next section I will say more about this connection. For now let us note that in his commentary on Aristotle's Nicomachean Ethics, and particularly on Aristotle's definition of good as "that to which all things are naturally inclined," Aquinas says that being the mover of natural appetitus is an effect of good, but a proper effect. ${ }^{58}$ That is, being the object of natural inclination is a proper or per se accident of good, rather than an attribute which inheres merely per accidens, which we can call a mere accident.

My claim against Duska's dual component interpretation-and against any essentialist interpretation-is that being the object of natural inclination (i.e., appetitus), or being genuinely factually desirable for humans, is not part of the essence or ratio of being good, but is a proper effect and accident of the good. One might be tempted to say, then, that although being the object of actual natural inclination is not part of the essence or ratio of good, it is a necessary attribute of the good as such. Although Aquinas does sometimes seem to suggest that proper accidents are necessary and some of his commentators have suggested they are, ${ }^{59}$ this must be qualified, at least with respect to potencies of the soul, as desires are. For Aquinas holds that the potencies of the soul are proper accidents of a human being, ${ }^{60}$ and among these is the power of sight and hearing. ${ }^{61}$ Yet he certainly recognized that some people are blind and deaf, and are not actually able to see and hear. He explains this by saying that although one may have a potency, a first actuality, due to the soul, the exercise,

58. Thomas Aquinas Sententia libri Ethicorum 1.1 in the Leonine Opera omnia 47 (Rome: Editori San Tomasso, 1969), p. 5, lines 155-160.

59. Aquinas writes that "what belongs to a thing per se is in that thing of necessity, always and inseparably," in the Summa contra Gentiles 2.55, ed. C. Pera (Rome: Marietti, 1961), no. 1432. Further, he writes elsewhere, "necessity results from form, because whatever is consequent on form is of necessity in the subject" (Summa theol. 1.86.3). These passages are quoted by Petrus Hoenen, who comments, "the necessity of this relationship between [proper accidents] and their substrate is an absolute necessity." See his Reality and Judgement According to St. Thomas Aquinas, trans. H. F. Tiblier (Chicago: Regnery, 1952), p. 118.

60. "A potency of the soul flows from its essence, not through a transformation, but as a certain natural result, and it is simultaneous with the soul" (Summa theol. 1.77.7 ad 1).

61. Thomas Aquinas Summa theol. 1.78.3. 
or second actuality, of this potency is impeded by some defect in the matter. Hence, although a mere potency due to the form may be necessary for all who possess that form, still this potency may not be able to be exercised if there is a defect in the matter, and thus there may be members of the kind who cannot exercise the potency. Thus, although all creatures of a kind may have a mere potency to desire or be inclined to their good, it is not necessarily the case that they actually desire or are so inclined. It is therefore not necessary that all creatures have an actual natural inclination to their good. It is only necessary that they have a potency to an actual inclination in virtue of their form.

\section{OBJECTIONS AND REPLIES}

The reader is probably aware of a serious problem for the view put forward so far. I have claimed that being the object of natural inclination is not part of the essence or ratio of good, but is only a proper effect or accident of being good. Yet in Summa theologiae 1-2.94.2 Thomas says that the ratio of good is 'quod omnia appetunt', 'that to which all things are naturally inclined'. In another place he calls this formula a definition. ${ }^{62}$ It seems obvious enough that if this formula expresses the ratio of good, and indeed if it is a definition of 'good', then being object of natural inclination is part of the ratio or essence of good. Furthermore, I have argued that Aquinas's view was that we infer what is good for us by considering that to which we are inclined (i.e., that which we genuinely factually desire). But how can we make sense of this if being the object of natural inclination is not part of the ratio of good?

The first objection is, I believe, the strongest and I will take much longer to respond to it. My response will consist largely of a discussion of Aquinas's views on our ideas ("rationes") in general and the definitions which express them. This area is obviously broad and complex, and my treatment in this paper must be somewhat sketchy. Yet I hope to present and argue for the outline of an interpretation of Aquinas on these issues which will enable me to respond to this

62. Thomas Aquinas Sent. Ethic. 1.1 (Leonine 47:5.5.149). 
objection and which, I believe, will illumine Aquinas's general views on rationes and definitions. 63

First of all, let us recall that although the ideal sort of definition after which Aquinas strives mentions only essential attributes, he does recognize and use definitions which mention accidents of the definiendum. For instance, in Summa theologiae 1.29.1 ad. 3 Thomas tells us that, having perceived something as common as fire, we can be ignorant of the substantial difference of its proper definition, and must allow 'hot, dry body' - a definition which employs proper accidentsto stand in as the definition of fire. Again, in Summa theologiae 1.77.1 ad.7 he writes:

Nevertheless because substantial forms, unknown to us of themselves, are known through their accidents, there is no difficulty with sometimes using accidents in place of substantial differences. 64

How is it, though, that accidents can be used to define an essence when the essential attributes are unknown? How can such a formula serve as a definition of that essence at all? Some light can be shed on these questions from Thomas's commentary on chapters 8-10 of Book II of Aristotle's Posterior Analytics. Several writers have recently claimed that these passages are important for understanding Aristotle's views on definition, ${ }^{65}$ but little has been written on how Aquinas's commentary on these chapters might illumine his views on definition. According to Thomas, in chapter 8 of Book II Aristotle considers two cases of an imperfect apprehension:

Aristotle says that we can know scientifically that some thing is, and yet not know from this what the thing is; and this can happen in two ways. In the first way, we know some accident of the thing, as, for example, if

63. See my "Aquinas on the Veracity of the Intellect" for a somewhat fuller presentation of and argument for this interpretation.

64. Thomas Aquinas Summa theol. 1.77 .1 ad 7.

65. Some of these are: Robert Bolton, "Essentialism and Semantic Theory in Aristotle," Philosophical Review 85 (1976): 514-544; J. A. Ackrill, "Aristotle's Theory of Definition: Some Questions on An. Post. II.8-10," Aristotle on Science: The 'Posterior Analytics', ed. Enrico Berti (Padua: Antenore, 1981), pp. 359-384; and Richard Sorabji, Necessity, Cause and Blame: Perspectives on Aristotle's Theory (London: Duckworth, 1980), pp. 195-201. 
we think that a hare exists on the basis of quick movement. In a second way, we know something on the basis of its essence. 66

The first sort of partial knowledge, of accidents only, is quite deficient: (1) it is insufficient for any sort of scientific knowledge of the essence; (2) it does not constitute scientific knowledge that the substance exists; (3) it is not in potency to a full grasp of the essence. In the second case, something of the essence is grasped. The second sort of apprehension is much more adequate: (1) it does qualify as some sort of grasp of the essence; (2) it does constitute scientific knowledge that the substance exists; and (3) it is in potency to full scientific knowledge of the essence. One instance of this is had, as Aquinas writes, "if we grasp that man is on the basis of the fact that man is rational, while not yet knowing the other attributes which complete the essence of man." 67 Furthermore, this is the sort of case Thomas takes Aristotle to be speaking of when he offers the following accounts:

(1) The definition of 'thunder' is 'a certain noise in the clouds'.

(2) The definition of 'eclipse' is 'a certain privation of light'.

(3) The definition of 'man' is 'a certain animal'.

(4) The definition of 'soul' is 'that which moves itself.

When one has a grasp of some part of the essence, one grasps the essence partially and is in potency to a full apprehension. It is important for us to appreciate, however, what the imperfect idea is not. It is not, for some essential attribute, the idea of whatever has that attribute. In the case of thunder, for instance, the claim is not:

(5) The definition of 'thunder' is 'any noise in the clouds'.

This would not be an idea of thunder at all, for, as Thomas says, "not every 'noise in the clouds' is thunder." 68 If the cognitive grasp in question is to be the idea of thunder, then it must be an idea of the property being a noise in the clouds as part of a yet-to-bediscovered essence. This would involve a presupposition that there is some essence yet to be discovered, and some way in which that essence is signified. The idea must be that expressed by:

66. Thomas Aquinas Expos. Post. 2.7 (Leonine $1 * / 2: 199.126-131$ ).

67. Thomas Aquinas Expos. Post. 2.7 (Leonine 1*/2:199.133-135).

68. Thomas Aquinas Expos. Post. 2.7 (Leonine 1*/2:199.146-147). 
(6) The definition of 'thunder' is 'a certain sort of noise in the clouds' ("quaedam sonam in nubibus"). 69

I am taking the "certain sort of" as a reference to the as-yet-notfully-known essence. The reference would seem to be in virtue of the instances of the properties which are taken as part of the essence; the phrase in question refers to their underlying cause. As he says in an analogous case, when speaking of using accidentia propria in place of unknown essential properties, the accidentia propria are used in the definition as "effects of the substantial forms, and as making these forms known ('manifestant eas')."70 They are used to identify demonstrably the underlying essence which is to be discovered.

In the chapters of the Posterior Analytics under consideration, Aristotle and Aquinas discuss only essences the study of which falls to what Aquinas calls natural philosophy or physics. Aquinas follows what he believes is Aristotle's view, that when our grasp of a certain natural essence is deficient, when some essential attributes are unknown to us, we may employ a definition which mentions accidental attributes. The yet-to-be-fully-grasped essence is identified demonstrably as the underlying cause of the instances of the accidental attribute(s) specified in the definition. Such a definition specifies certain accidental attributes of the essence and refers to the essence, which is not itself fully known, as the underlying cause. Henceforth I will call such definitions 'reference-involving' definitions; I will say that terms which are referentially defined in this way possess semantic depth, ${ }^{71}$ for the essence signified (in Aquinas's sense of 'significare') may be beyond what the language-users fully apprehend.

The reader will perhaps have realized that this view which I am attributing to Aquinas is very close to so-called recent accounts of natural kind terms which arose out of the work of Hilary Putnam and Saul Kripke, and which has been developed by Colin McGinn and Tyler Burge, among others. Several writers have found such a view in Aristotle. ${ }^{72}$ Although I also think Aristotle did hold such a view, the evidence that he did is somewhat ambiguous. Aquinas, I believe,

69. Thomas Aquinas Expos. Post. 2.7 (Leonine 1*/2:199.144).

70. Thomas Aquinas Summa theol. 1.29.1 ad 3.

71. I take this expression from David Charles, who uses it in an unpublished manuscript on Aristotle's understanding of definition.

72. See note 65 above. 
embraced and put forward a more sophisticated and clearer version of this sort of account. ${ }^{73}$

Let us return to the ratio boni and its definition. I want to argue that Aquinas's use of 'good' and its definition can be understood as analogous to 'thunder' and its definition. I contend that 'good' is a term with a certain sort of semantic depth, and that its definition, 'that to which all things are naturally inclined,' is reference-involving. On this reading, although being the object of natural inclination is a non-essential attribute of being good, it is used in the definition of the term to refer to that attribute of being good which is in fact what is the object of natural inclination.

This reading is strongly recommended by previous results of this paper. In section II I argued that Aquinas held that being the object of natural inclination is not essential to being good; however, as pointed out above, Aquinas defines good in terms of natural inclination. The reading under consideration allows us to reconcile these two apparently incompatible claims of Aquinas. Yet there is also strong support for this reading from what Aquinas actually says about the formula expressing the ratio of good.

In Summa theologiae 1-2.94.2 Aquinas gives us the definition of 'bonum' as 'quod omnia appetunt', but he does not elaborate there upon this definition. The definition is, of course, taken from the first lines of Aristotle's Nicomachean Ethics, and in Aquinas's commentary on the Ethics we do find a discussion of it. Aristotle begins with the well-known lines:

Every art and every inquiry, and similarly every action and choice, is thought to aim at some good; and for this reason the good has rightly been declared to be that at which all things aim..$^{74}$

73. One writer who thinks the Kripke-Putnam account of natural kind terms is relevant to Aquinas is Janice Schultz, who discusses it extensively in 'Necessary Moral Principles." However, Schultz does not discuss the Kripke-Putnam account with respect to an incomplete grasp of an essence and reference-involving definitions. Her concern is to show that per se predications of proper accidents may be necessarily true, and yet informative. Schultz, however, would not be in agreement with my account of the ratio of good and its definition, for she offers a different account in her "Thomistic Metaethics and a Present Controversy."

74. Aristotle Nicomachean Ethics 1.1 1094a1-3, trans. W. D. Ross, rev. J. O. Urmson, in The Complete Works of Aristotle, ed. Jonathan Barnes (Princeton: Princeton University Press, 1984) 2:1729. 
In the Latin translation, the second phrase of the quote (which comes after the semicolon in the translation above) is: "Ideo bene enunciaverunt, bonum quod omnia appetunt."75 Thus in this phrase Aristotle presents what Aquinas takes as the definition of 'good', 'that to which all things are naturally inclined'. Aquinas begins his comment on this second phrase by saying, "[Aristotle] makes his claim manifest through the definition of good." 76 He notes, however, that there is a certain peculiarity about this definitional formula, for "the good is counted among the first things." $77 \mathrm{He}$ goes on to explain:

The first things cannot be made known through what is prior, but is made known through what is posterior, as causes [are made known] through their proper effects. And since the good is properly the spring of appetitus, the good is marked off [describitur] with respect to the movement of appetitus, as the moving power is customarily made manifest with respect to what is moved. Thus [Aristotle] says that philosophers have rightly declared that the good is 'that to which all things are naturally inclined [appetunt]'. ${ }^{78}$

Aquinas says clearly that the definition, 'that to which all things are naturally inclined', employs what is posterior to and an effect of goodness-viz., the ability to move appetitus, or natural inclinationto define what is simple and primary, goodness. Being able to move natural inclination, which, in the case of humans, is being genuinely factually desirable, cannot then be part of the essence or ratio of good. If it were, being good could not be said to be simple and prior to being able to move appetitus, for the latter would be (at least partially) constitutive of the former. We must, therefore, take being able to move appetitus (and being genuinely factually desirable) to be a nonessential attribute of goodness, and to be used in the definition to refer to the simple and primary essence of goodness. Thus, the definition of 'good' is reference-involving and the term has semantic depth.

It seems, then, that the definition of 'good' as 'that to which all things are naturally inclined', as Aquinas understands it, does not undermine my contention that being the object of natural inclination is not part of the essence or ratio of good. On the contrary, it supports

75. Aristotle, as Thomas reads him in Sent. Ethic.

76. Thomas Aquinas Sent. Ethic. 1.1 (Leonine 47:5.149).

77. Thomas Aquinas Sent. Ethic. 1.1 (Leonine 47:5.150-151).

78. Thomas Aquinas Sent. Ethic. 1.1 (Leonine 47:5.153-160). 
it. For when Aquinas discusses the definition he implies that it is a reference-involving definition which employs an accidental attribute to specify an essence.

There is, however, an important difference between good and its definition and terms from what Aquinas calls natural philosophy, such as thunder and eclipse, and their respective definitions. In the case of thunder and eclipse, it may be argued, although our grasp of these essences is initially imperfect and impartial, there is reason to believe that through prolonged scientific investigation, we can come to a full grasp of these essences. Indeed, Aquinas follows Aristotle's attempts to arrive at a fuller understanding of thunder and eclipses. ${ }^{79}$ It does not seem that we can come to a fuller grasp of the essence of goodness in this way, at least given our cognitive state on this earth. 80 We can, of course, sharpen our ability to make practical moral judgments, but this will get us no nearer a full grasp of good and a definition of 'good' which does not employ accidental attributes.

For terms in Aquinas's natural philosophy, there is an expectation that through scientific inquiry reference-involving definitions may be replaced by definitions which are not reference-involving. In the case of 'good' there seem to be no such expectation, given our cognitive state in this life. An objection may be raised, then, that because the definitions of 'thunder' and 'eclipse' are provisional in a way in which that of 'good' is not, this in some way undermines my contention that 'good' has semantic depth and a reference-involving definition, and my claim that the attribute mentioned in the definition is a nonessential attribute of goodness.

This objection is without great force. There is no reason to think that referential definitions must be provisional until scientific progress brings us to a more adequate formulation. Another term which Aquinas seems clearly to recognize as having semantic depth is 'God'. The term 'God' for Aquinas is not the proper name of an individual, but a general term used "to signify the divine nature." 81 As Thomas says, the essence of God is beyond our intellectual grasp in this life,

79. See Aquinas's commentary on Posterior Analytics 1.13 for a discussion of eclipses, and on 2.10 for a discussion of thunder.

80. The blessed who enjoy the beatific vision have a fuller grasp of goodness, for they see the essence of God, who is goodness. But they enjoy a cognitive state which cannot be enjoyed by anyone in this life on earth. Summa theol. 1-2.5.3 and 5 .

81. Thomas Aquinas Summa theol. 1.13.8. 
and any understanding we have of God is from his effects, from the creatures he has created. ${ }^{82}$ Any definition of the term, then, must be in terms of his effects in creation. Being creator of the world, however, is an accidental attribute of God, 83 and this accidental attribute is used to define referentially the divine nature; so the term has semantic depth and a referential definition. In the case of God, Aquinas clearly thinks there is no chance that we may progress toward a full grasp of the divine nature in this life through scientific investigation. ${ }^{84}$ In this respect, then, 'good' is more like 'God' than like 'thunder', for the referential definition which employs accidental attributes is not provisional until scientific inquiry leads us to a more adequate grasp of the essence. It is, rather, the best definition we can have, given our cognitive state in this life.

I conclude, then, that the definition of good, 'that to which all things are naturally inclined,' is a reference-involving definition which employs an accidental attribute of goodness to specify the simple and prior essence. This conclusion enables us to reconcile the results of the previous section with Aquinas's definition of good. In light of this conclusion, it seems we must make a distinction among rationes which is not always clearly made by Aquinas. Given Aquinas's view that we can use a reference-involving definition to specify an essence which may not itself be fully understood, we must distinguish in such cases between an essence and our imperfect intellectual grasp of it. We must distinguish between the full intelligible structure of certain things, which exist in rebus in some way, and our apprehension of it. When our understanding of an essence is complete, then there is no difference between them. When our understanding is incomplete, as when we use reference-involving definitions, there is some difference between them. Thomas adopts no consistent terminology to mark this difference between the essence and our imperfect understanding, but it will be helpful for us to do so. I will henceforth cease to use 'idea' to translate 'ratio', the full intelligibility of the thing, and will use 'concept'. 85 When I speak of the intelligibility insofar as it is

82. Thomas Aquinas Summa theol. 1.13.1.

83. Thomas Aquinas Summa contra Gentiles 1.81.

84. Thomas Aquinas Summa theol. 1-2.5.3 and 5.

85. This term should not be confused with Aquinas's "conceptus," for he used this term to denote judgments. 
understood by us, I will use 'conception'. ${ }^{86}$ As was said, when our apprehension is perfect, the intelligible form in our understanding is identical with that in the thing; in this case our conception is identical with the concept. When our apprehension is imperfect, they differ.

A confusing feature of Aquinas's terminology is that he uses 'ratio' to refer to both concepts and our conceptions. Our intellect forms ideas by abstracting the intelligible from individuating, designated matter ("materia signata"), but not from common matter ("materia communis"), and this is the ratio expressed by the definition. 87 If our understanding of, say, a human being is perfect, the intelligible form in our intellects is identical with the intelligible structure of the thing, and we can speak of them both as ratio hominis. If the intelligible form is not fully grasped, as in the case of our understanding of thunder, we can speak of our definition of thunder and the intellectual form as grasped by our intellects, but this is not identical with the intelligible structure of the thing. So, similarly he can speak of something being good by an intrinsic form which is a similitude of the First Goodness, and also as the ratio of good as including being the object of natural inclination. This is understandable because he considers our imperfect conceptions to be inchoate forms which are in potency to be perfect conceptions, ${ }^{88}$ which are identical with the concept. Both the imperfect and perfect members of a species are called by the same name. Yet the matter is confusing, and has, I believe, confused many commentators on Aquinas.

My claim, then, is that although being the object of natural inclination is accidental to the concept of good, it is nevertheless central to our conception of good. This leads us to a response to the second objection raised at the start of this section, namely: how are we to

86. The terms 'concept' and 'conception' are derived from Frege, but I certainly do not want to suggest that Thomas accepted Fregean concepts. Nevertheless, it is meant to suggest that Thomas's natures as such have a certain existence independent of our understanding them. As Edwards argues (persuasively, to my mind), on a correct understanding of his view "Aquinas turns out to be almost as strong a realist as Duns Scotus." See Sandra Edwards, "The Realism of Aquinas," New Scholasticism 59 (1985): 79.

87. Thomas Aquinas Summa theol. 1.85.1; Expositio Super Librum Boethii de Trinitate 5.2 .

88. Thomas Aquinas Summa theol. 1.85.3. 
account for the fact that Aquinas infers what is good for humans from what their natural inclinations are, if these are accidental to being good? Clearly, we make inferences about things insofar as we understand the sorts of things they are. Hence, we make inferences on the basis of our conceptions of their form, and not necessarily on the basis of concepts. Since, in the case of good, the feature central to our conception is being the object of natural inclination, inferences about what is good for us are understandable based on that to which we think we are naturally inclined, in the sense of genuinely factually desiring. Of course, there may be a further question about why such an inference is rational, or why it produces knowledge ("scientia"), but this would require a lengthy treatment of Aquinas's epistemological views, which I cannot take up here. ${ }^{89}$

\section{CONCLUSION}

A deep difficulty for moral philosophers is that in their analysis of the nature of good they seem to be pulled in opposite directions. That something is good for us must provide some motivation for us to bring that thing about. Our good must be something that interests and attracts us. Hence, it is thought, being the object of our inclinations must be (at least) part of what it is to be good for us. This view leads one in the direction of moral subjectivism and moral relativism.

On the other hand, it seems that the fact that something is good or evil cannot depend on whether we are attracted to it or repulsed by it. As W. D. Ross wrote in his classic work The Right and the Good, "it is surely a strange reversal of the natural order of thought to say that our admiring an action either is, or is what necessitates, its being good. We think of its goodness as what we admire in it, and as something it would have even if no one admired it, something it has in itself." 90 This view moves us toward moral objectivism.

89. For a fuller discussion of Aquinas's epistemological views, see my "Knowledge, Faith and Philosophy in Thomas Aquinas," doctoral dissertation, Oxford University, 1989, especially chapter 1, "The Natural Light of the Intellect."

90. W. D. Ross, The Right and the Good (Oxford: Clarendon, 1930), p. 89. 
In this essay I have argued for an interpretation of Aquinas which goes some way toward accommodating both of these apparently conflicting intuitions. Our conception, our understanding, of good is as 'that to which all things are naturally inclined'. This definition takes an accidental attribute of goodness, being the ohject of creaturely natural inclinations (appetitus), and marks off the good as that which is the spring of such actual natural inclinations in the creatures on this earth. In this way an accidental attribute is used in the definition of 'good'. But although our own dispositions to desire are intimately involved in our understanding of and reasoning about what is good for us, nevertheless being good does not consist in being the object of such desires: rather, being able to move us to desire is an effect of and posterior to being good. As Aquinas writes, "bonum numeratur inter prima." 91

University of Notre Dame

91. Thomas Aquinas Sent. Ethic. 1.1. 